\title{
Decreased Brain-Derived Neurotrophic Factor Depends on Amyloid Aggregation State in Transgenic Mouse Models of Alzheimer's Disease
}

\author{
Shiyong Peng, ${ }^{1}$ Diego J. Garzon, ${ }^{1}$ Monica Marchese, ${ }^{1}$ William Klein, ${ }^{2,3}$ Stephen D. Ginsberg, ${ }^{4}$ Beverly M. Francis, ${ }^{5,6}$ \\ Howard T. J. Mount, ${ }^{5,6}$ Elliott J. Mufson, ${ }^{7}$ Ahmad Salehi, ${ }^{8}$ and Margaret Fahnestock ${ }^{1}$ \\ ${ }^{1}$ Department of Psychiatry and Behavioural Neurosciences, McMaster University, Hamilton, Ontario L8N 3Z5, Canada, ${ }^{2}$ Institute for Neuroscience, \\ Northwestern University, Evanston, Illinois 60611, ${ }^{3}$ Department of Neurobiology and Physiology, Northwestern University, Evanston, Illinois 60208, \\ ${ }^{4}$ Nathan Kline Institute, New York University School of Medicine, Orangeburg, New York 10962, 5 Division of Neurology, Department of Medicine, \\ University of Toronto, Toronto, Ontario M5S 3H2, Canada, ${ }^{6}$ Department of Physiology, University of Toronto, Toronto, Ontario M5S 1A8, Canada, \\ ${ }^{7}$ Department of Neurological Sciences, Rush University Medical Center, Chicago, Illinois 60612, and ${ }^{8}$ Department of Neurology, Stanford University, \\ Stanford, California 94305
}

Downregulation of brain-derived neurotrophic factor (BDNF) in the cortex occurs early in the progression of Alzheimer's disease (AD). Since BDNF plays a critical role in neuronal survival, synaptic plasticity, and memory, BDNF reduction may contribute to synaptic and cellular loss and memory deficits characteristic of AD. In vitro evidence suggests that amyloid- $\beta(\mathrm{A} \beta)$ contributes to BDNF downregulation in $\mathrm{AD}$, but the specific $\mathrm{A} \beta$ aggregation state responsible for this downregulation in vivo is unknown. In the present study, we examined cortical levels of BDNF mRNA in three different transgenic AD mouse models harboring mutations in APP resulting in A $\beta$ overproduction, and in a genetic mouse model of Down syndrome. Two of the three $\mathrm{A} \beta$ transgenic strains (APP ${ }^{N L h}$ and TgCRND8) exhibited significantly decreased cortical BDNF mRNA levels compared with wild-type mice, whereas neither the other strain (APP ${ }^{\text {swe } /}$ PS-1) nor the Down syndrome mouse model (Ts65Dn) was affected. Only $A P P^{N L h}$ and TgCRND8 mice expressed high A $\beta_{42} / \mathrm{A} \beta_{40}$ ratios and larger SDS-stable $\mathrm{A} \beta$ oligomers ( $\sim 115 \mathrm{kDa})$. TgCRND8 mice exhibited downregulation of BDNF transcripts III and IV; transcript IV is also downregulated in AD. Furthermore, in all transgenic mouse strains, there was a correlation between levels of large oligomers, $\mathrm{A} \beta_{42} / \mathrm{A} \beta_{40}$, and severity of $\mathrm{BDNF}$ decrease. These data show that the amount and species of $\mathrm{A} \beta$ vary among transgenic mouse models of $\mathrm{AD}$ and are negatively correlated with BDNF levels. These findings also suggest that the effect of $\mathrm{A} \beta$ on decreased BDNF expression is specific to the aggregation state of $\mathrm{A} \beta$ and is dependent on large oligomers.

\section{Introduction}

Alzheimer's disease (AD) is the predominant form of dementia in the elderly. Pathological features of AD include the presence of amyloid plaques, soluble amyloid- $\beta(A \beta)$ oligomers, neurofibrillary tangles, neuritic dystrophy, synaptic loss, and eventual neurodegeneration (Mirra et al., 1991; Hyman, 1997). Mutations in the amyloid precursor protein $(A P P)$ and presenilin 1 and 2 (PS-1 and $P S-2)$ genes cause familial $\mathrm{AD}(\mathrm{FAD})$, and all identified pathogenetic mutations lead to overproduction of amyloid- $\beta$

Received Sept. 29, 2008; revised April 26, 2009; accepted May 14, 2009.

This work was supported by grants from the Scottish Rite Charitable Foundation of Canada, the Alzheimer's Association, and the Canadian Institutes of Health Research to M.F., by graduate fellowships from the Alzheimer's Society of Canada and from the Scottish Rite Charitable Foundation of Canada to D.J.G., by a grant from the Ontario Mental Health Foundation to H.T.J.M., and by National Institute on Aging Grant AG10688 to E.J.M. We thank Bernadeta Michalski for expert technical assistance. We thank Cephalon for the generous gift of transgenic mouse tissue.

Correspondence should be addressed to Dr. Margaret Fahnestock, Department of Psychiatry and Behavioural Neurosciences, McMaster University, 1200 Main Street West, Hamilton, ON L8N 3Z5, Canada. E-mail: fahnest@mcmaster.ca.

D. J. Garzon's present address: Bristol-Meyers Squibb, Montreal, QC H4S OA4, Canada.

D0I:10.1523/JNEUROSCI.4736-08.2009

Copyright $\odot 2009$ Society for Neuroscience $\quad$ 0270-6474/09/299321-09\$15.00/0
$(\mathrm{A} \beta)$ or its most fibrillogenic form $\left(\mathrm{A} \beta_{42}\right)$ (Selkoe, 1994). Assemblies of the $A \beta$ fragment are neurotoxic in vitro (Yankner, 2000), cause synaptic degeneration (Lacor et al., 2007; Walsh and Selkoe, 2007), and interfere with long term potentiation, a form of memory consolidation (Lambert et al., 1998; Walsh et al., 2002). However, the magnitude of $A \beta$ toxicity in vivo remains unclear. In part, this controversy appears to be explained by the observations that distinct aggregation states of $A \beta$ display differential toxic properties. In fact, there exist different soluble $A \beta$ aggregates exhibiting a broad range of sizes (Klein, 2002; LeVine, 2004 ), and specifically which soluble oligomeric aggregates of $A \beta$ could be the most toxic forms and what is the downstream mechanism of $A \beta$ neurotoxicity are still under debate (Gong et al., 2003; Lesné et al., 2006; Townsend et al., 2006).

Recent evidence suggests $\mathrm{A} \beta$-associated neurotoxicity may be a consequence of brain-derived neurotrophic factor (BDNF) deficiency. Several studies indicate that the cortex and hippocampus, areas of the brain associated with learning and memory, exhibit both extensive amyloid pathology and decreased levels of BDNF in AD (Phillips et al., 1991; Connor et al., 1997; Ferrer et al., 1999; Hock et al., 2000; Holsinger et al., 2000; Garzon et al., 
Table 1. Profile of transgenic mouse models of AD used in this study

\begin{tabular}{|c|c|c|c|c|}
\hline Transgenic mouse & Promoter & Construct & Mutation $^{a}$ & Background \\
\hline $\begin{array}{l}A P P^{N L h} / P S-1^{P 264 L} \\
A P P^{N L h} \\
P S-1^{P 264 L}\end{array}$ & Endogenous & Gene-targeted APP and PS-1 mutations & $\begin{array}{l}\text { Swe, PS-1 } \\
\text { Swe } \\
\text { PS-1 (P264L) }\end{array}$ & $129 / C D-1$ \\
\hline $\begin{array}{l}\text { APP }{ }^{\text {swe }} / P S-1^{M 146 V} \\
P S-1^{M 146 V}\end{array}$ & $\begin{array}{l}\text { Hamster PrP } \\
\text { Human PDGF }\end{array}$ & $\begin{array}{l}\text { hAPP695 } \\
\text { hPS-1 }\end{array}$ & $\begin{array}{l}\text { Swe + PS-1 } \\
\text { PS-1 (M146V) }\end{array}$ & $\left(\mathrm{C} 57 \mathrm{~B} 6 / \mathrm{S} J \mathrm{~L} \times(57 \mathrm{~B} 6) \times\left(\right.\right.$ Swiss-Webster $/{\mathrm{B} 6 \mathrm{D} 2 \mathrm{~F}_{1}} \times \mathrm{B} \mathrm{DD} 2 \mathrm{~F}_{1})$ \\
\hline TgCRND8 & Syrian hamster PrP & hAPP695 & Swe + Ind & $\mathrm{C} 57 \mathrm{BL} / 6 \mathrm{~J} \times(3 \mathrm{H} / \mathrm{HeJ} / \mathrm{C} 57 \mathrm{BL} / 6 \mathrm{~J}$ \\
\hline
\end{tabular}

${ }^{a}$ APP mutations: Swe, Swedish; Ind, Indiana.

${ }^{b}$ The construct was composed of the human APP695 CDNA under control of the hamster PrP promoter and the human PS-1 CDNA under control of the human PDGF promoter.

2002; Peng et al., 2005). Interestingly, BDNF protein levels are significantly decreased in preclinical and early stages of $\mathrm{AD}$, and this reduction correlates with clinical neuropsychological scores (Peng et al., 2005). Since BDNF is critical for neuronal survival and function (Siegel and Chauhan, 2000; Mufson et al., 2007) and for synaptic plasticity and learning and memory (Korte et al., 1995; Patterson et al., 1996; Lu, 2003; Bramham and Messaoudi, 2005; Nagahara et al., 2009), which are compromised in AD, it is important to understand which $\mathrm{A} \beta$ species drive the reduction of $\mathrm{BDNF}$ in $\mathrm{AD}$. In vitro data demonstrate that soluble forms of $\mathrm{A} \beta$ decrease BDNF mRNA expression and compromise BDNF intracellular signaling in both primary rat neurons and human neuroblastoma cells (Tong et al., 2001, 2004; Garzon and Fahnestock, 2007). Therefore, amyloid-induced neurodegeneration may be a consequence of reduced BDNF. However, whether $\mathrm{A} \beta$ assemblies downregulate BDNF in vivo, and which $\mathrm{A} \beta$ assembly state is responsible for $\mathrm{BDNF}$ downregulation, have not been elucidated. In this study, we measured levels of BDNF mRNA and $\mathrm{A} \beta_{42} / \mathrm{A} \beta_{40}$ ratios and characterized the state of $A \beta$ in three different transgenic mouse models of AD (Table 1) containing mutations in $A P P$, two of these in combination with PS-1 mutations, and in a mouse model of Down syndrome (segmental trisomy 16) containing an additional copy of App.

\section{Materials and Methods}

Transgenic mice. All animal experiments were performed in accordance with the Canadian Council on Animal Care Guide for the Care and Use of Laboratory Animals. Table 1 summarizes the characteristics of each transgenic mouse line. Construction of $A P P^{N L h}, P S-1^{P 264 L}$, and $A P P^{N L h} /$ $P S-1^{P 264 L}$ mice (Cephalon) has been described previously (Reaume et al., 1996; Flood et al., 2002). Briefly, the A $\beta$ portion of the App gene has been "humanized" and the Swedish mutation (K670N/M671L) inserted (Reaume et al., 1996). A single amino acid substitution in PS-1 (P264L) has been knocked in. Unlike the other mice in this study, these mice express APP and PS-1 mRNA at normal levels under control of their endogenous promoters. APP ${ }^{N L h} / P S-1^{P 264 L}$ mice demonstrate elevated $\mathrm{A} \beta$ levels and plaque deposition at 6 months of age (Flood et al., 2002), whereas plaque deposition was not detected in either the $A P P^{N L h}$ or the $P S-1^{P 264 L}$ single mutant mice up to 22 months (Flood et al., 2002). Mice were killed at 15 and 18 months of age. After removal of the cortical hemispheres, tissue was flash frozen in liquid nitrogen and stored at $-80^{\circ} \mathrm{C}$.

The construction of the APP $P^{\text {swe }} / P S-1^{M 146 V}$ mice is well documented (Kurt et al., 2001; Sadowski et al., 2004). These double transgenic mice are a cross between Tg2576 mice expressing the Swedish APP mutation K670N and M671L (Hsiao et al., 1996) and H8.9 mice expressing the mutant PS-1 M146V (McGowan et al., 1999). These mice overexpress mutated APP and PS-1 under control of the hamster prion protein (PrP) and PDGF promoters, respectively, and have extensive plaque deposition throughout the cortex and hippocampus by 6 months of age (McGowan et al., 1999). The age of the mice at killing was between 19 and 24 months.

TgCRND8 mice contain the human APP695 cDNA cassette with a double APP mutation (Swedish and Indiana V717F) governed by the Syrian hamster PrP promoter. Detailed construction of this mouse strain has been described previously (Chishti et al., 2001). These mice overexpress APP and produce elevated $\mathrm{A} \beta_{42}$ levels at 4 weeks, with plaque deposition by 3 months (Chishti et al., 2001). The age of the mice at killing was 11.4 months.

Ts65Dn mice display triplication of a number of genes orthologous to the human Down syndrome locus, including the App gene, on an additional copy of a segment of chromosome 16 (MMU16) translocated close to the centromere of chromosome 17 (Reeves et al., 1995). These mice serve as a genetic mouse model for Down syndrome and exhibit increased levels of App. The age at killing was 18-21 months.

RNA isolation, DNase treatment, reverse transcription, and absolute quantitative PCR. Frozen cortical samples (100 mg wet weight) were sonicated with a Sonic dismembrator model 100 (Fisher Scientific) in 1 $\mathrm{ml}$ of Trizol (Invitrogen), and RNA was isolated with RNeasy spin columns (Qiagen). The procedure for RNA isolation was followed as specified by Qiagen. RNA purity was confirmed by spectrophotometry $\left(A_{260} / A_{280}>1.7\right)$, and RNA integrity was visualized by agarose gel electrophoresis.

One microgram of RNA was treated with $2 \mathrm{U}$ of Turbo DNA-free (Ambion). For reverse transcription (RT), Invitrogen's protocol and reagents for Superscript II were used. The final volume of $20 \mu \mathrm{l}$ contained $250 \mathrm{ng}$ of random primers, $0.5 \mathrm{~mm}$ deoxynucleotide triphosphates ( $0.5 \mathrm{~mm}$ each of dATP, dTTP, dCTP, and dGTP), $1 \times$ first-strand buffer, $0.05 \mathrm{~mm}$ dithiothreitol, $2 \mathrm{U}$ of RNaseOUT, and $200 \mathrm{U}$ of Superscript II RT (Moloney murine leukemia virus reverse transcriptase). As a control, $1 \mu \mathrm{g}$ of RNA was treated according to the same protocol with addition of water instead of the RT enzyme ("noRT” control).

Real-time PCR was performed in a Stratagene MX3000P using the DNA binding dye SYBR Green (Platinum SYBR Green qPCR SuperMix UDG, Invitrogen). The $20 \mu$ l PCR mix contained $1 \times$ qPCR SuperMix, forward and reverse primers, $30 \mathrm{~nm}$ ROX reference dye (Stratagene), and cDNA from 50 ng of RNA or reference standard for absolute quantification. Forward and reverse primers were used at $300 \mathrm{~nm}$ for all targets except for $\beta$-actin, for which forward and reverse primers were used at $150 \mathrm{nM}$. Forward and reverse primers were as follows: total mouse BDNF, 5' CAG CGG CAG ATA AAA AGA and 5' TCA GTT GGC CTT TGG ATA; exon I, 5' AGT CTC CAG GAC AGC AAA GC and 5' TCG TCA GAC CTC TCG AAC CT; exon III, 5' CTT CCA TCC CTC CCT CAT TT and 5' CTT CCC TTG AGA AGC AGG AG; exon IV, 5' AGA GCA GCT GCC TTG ATG TT and 5' TCG TCA GAC CTC TCG AAC CT; exon VI, 5' GCT TTG TGT GGA CCC TGA GT and 5' TTC GAT GAC GTG CTC AAA AG; and $\beta$-actin, 5' CTG ACA GGA TGC AGA AGG and 5' GAG TAC TTG CGC TCA GGA. A "no-template" control was added, which consisted of all the reagents listed above for real-time PCR, except the cDNA template was replaced with water. Levels of BDNF and $\beta$-actin were determined using absolute quantification (Garzon and Fahnestock, 2007). Standards for total BDNF, BDNF transcripts, and $\beta$-actin were obtained from purified PCR products using the primers listed above. Only experiments with an $R^{2}$ of $>0.997$ and a PCR efficiency of between 90 and $100 \%$ were used for analysis. All unknowns, no-RT, and notemplate controls were run in triplicate. The following thermal profile was used for all measurements: $2 \mathrm{~min}$ at $50^{\circ} \mathrm{C}, 2 \mathrm{~min}$ at $95^{\circ} \mathrm{C}$ followed by 40 cycles of $95^{\circ} \mathrm{C}$ for $15 \mathrm{~s}, 58^{\circ} \mathrm{C}$ for $30 \mathrm{~s}$, and $72^{\circ} \mathrm{C}$ for $30 \mathrm{~s}$. After PCR, a dissociation curve verified that no secondary products had formed.

Tissue homogenates for Western blotting. A small amount of tissue 
(from 0.012 to $0.05 \mathrm{~g}$ ) was homogenized with a Sonic dismembrator model 100 (Fisher Scientific) directly from the frozen state in $10 \mu \mathrm{l}$ per mg tissue of homogenization buffer (HB) (0.05 M Tris, pH 7.5, $10 \mathrm{~mm}$ EDTA, $0.5 \%$ Tween $20,1 \mu \mathrm{g} / \mathrm{ml}$ leupeptin, $2 \mu \mathrm{g} / \mathrm{ml}$ aprotinin and pepstatin, and $100 \mu \mathrm{g} / \mathrm{ml}$ PMSF) on ice. The homogenates were incubated for $5-10 \mathrm{~min}$ on ice and then centrifuged at $12,000 \times g$ for $15 \mathrm{~min}$ at $4^{\circ} \mathrm{C}$. Supernatants were transferred into autoclaved prechilled $1.5 \mathrm{ml}$ tubes and stored at $-80^{\circ} \mathrm{C}$ for use. Total protein concentrations for all homogenates were assayed with a DC protein assay kit (Bio-Rad).

Calcium precipitation. Calcium treatment can partially separate different forms of $A \beta$ assemblies and provides useful information about species that are present (Isaacs et al., 2006). A slight modification of the published method was applied to homogenates from an $A P P^{N L h}$ / $P S-1^{P 264 L}$ mouse. Briefly, $20 \mu \mathrm{l}$ of $20 \mathrm{~mm}$ calcium solution $\left(\mathrm{CaCl}_{2}\right.$ in $\mathrm{HB}$ without EDTA) was added to $20 \mu \mathrm{l}$ (total $220 \mu \mathrm{g}$ ) of homogenized protein. A parallel sample of homogenate was diluted with $20 \mu \mathrm{l}$ of $\mathrm{HB}$ instead. After a $24 \mathrm{~h}$ incubation at $37^{\circ} \mathrm{C}$, pellets were spun down at $1500 \times g$ for $3 \mathrm{~min}$ and resuspended in $1 \times$ loading buffer $(0.06 \mathrm{M}$ Tris-HCl, pH 6.8, $8 \%$ SDS, $10 \%$ glycerol, $5 \% \beta$-mercaptoethanol, $0.001 \%$ bromophenol blue), and both pellets and supernatants were examined by Western blotting.

Western blotting for $A \beta$. Protein homogenates $(30 \mu \mathrm{g})$ from transgenic and Ts65Dn mice were separated on $12 \%$ SDS-polyacrylamide gels at $120 \mathrm{~V}$ for $70 \mathrm{~min}$. Proteins were transferred onto PVDF membranes in transfer buffer [ $25 \mathrm{~mm}$ Tris, $192 \mathrm{~mm}$ glycine, 20\% (v/v) methanol] for $2 \mathrm{~h}$ at $110 \mathrm{~V}$ at $4^{\circ} \mathrm{C}$ and blocked for $1 \mathrm{~h}$ at room temperature in Tris-buffered saline-Tween 20 (TBS-T) [50 mm Tris, pH 8.0, $133 \mathrm{~mm} \mathrm{NaCl}, 0.2 \%$ (v/v) Tween 20] with $10 \%$ (w/v) Carnation nonfat milk powder. The blots were incubated with a 1:3000 dilution $(0.34 \mu \mathrm{g} / \mathrm{ml}$ ) of $6 \mathrm{E} 10$ (monoclonal anti-A $\beta$ antibody, Signet Laboratories), which recognizes all species of $\mathrm{A} \beta$ aggregates (Lesné et al., 2006), overnight at $4^{\circ} \mathrm{C}$ in TBS-T. After being washed in TBS-T, membranes were incubated in a 1:5000 dilution of HRP-conjugated sheep anti-mouse IgG secondary antibodies (GE Healthcare) in TBS-T with $5 \%$ nonfat milk powder for $1 \mathrm{~h}$ at room temperature. Finally, a chemiluminescence system (ECL, GE Healthcare), followed by exposure to CL-XPosure x-ray film (Thermo Fisher Scientific), was used to detect immunoreactive protein. The same blot was reprobed with anti- $\beta$-actin as the loading control after 1 or $2 \mathrm{~d}$, allowing for the decay of anti-A $\beta$ signals. To characterize $\mathrm{A} \beta$ assemblies, Western blots were cut into thirds along the molecular weight marker lanes (Fermentas) and incubated with a 1:2000 dilution of either the amyloid-derived diffusible ligand (ADDL)-selective antibody NU-2 (Lambert et al., 2007), the APP-specific antibody 22C11 (Millipore), or 6E10. Blocking buffer (Li-Cor Biosciences) mixed 1:1 with PBS plus $0.05 \%$ Tween 20 was substituted for TBS-T-milk powder. The secondary antibody was IRDye $800 \mathrm{CW}$ goat anti-mouse (Li-Cor Biosciences), used at a dilution of 1:8000 and detected using Odyssey infrared system version 1.2 (Li-Cor Biosciences). All Westerns were repeated in three independent experiments except for Ts65Dn mice, which were analyzed in two separate Western blotting experiments.

ELISA for $A \beta_{42}$ and $A \beta_{40}$. Homogenates were appropriately diluted to equal protein concentrations with sample washing buffer (supplied from the kit) and then assayed for total $\mathrm{A} \beta_{40}$ and $\mathrm{A} \beta_{42}$ using a commercially available sandwich-type ELISA (CRP). This ELISA had a detection limit of $12 \mathrm{pg} /$ well for $\mathrm{A} \beta_{40}$ and $\mathrm{A} \beta_{42}$. The values for $\mathrm{A} \beta_{40}$ and $\mathrm{A} \beta_{42}$ were calculated as picograms per milliliter.

Quantitative and statistical analysis. Results were obtained as copies per nanogram of total RNA by use of Stratagene MxPro software and were normalized as a ratio of BDNF or transcript/ $\beta$-actin. The volumes of the large-oligomer band and its corresponding $\beta$-actin band were determined by densitometry of films using an HP Scanjet Scanner (Hewlett-Packard Development) and Scion Image Beta 4.01 acquisition and analysis software (Scion). Means of triplicates were used for statistical analysis by one-way ANOVA with post hoc Tukey test for pairwise group comparisons or unpaired Student's $t$ tests where indicated, with $95 \%$ confidence interval (SPSS version 14 software, SPSS). Correlations between large oligomers or $\mathrm{A} \beta_{42} / \mathrm{A} \beta_{40}$ ratio and BDNF mRNA levels were assessed with Kruskal-Wallis test and Spearman rank correlation. The level of statistical significance was set at 0.05 .

\section{Results}

\section{BDNF mRNA levels are reduced in some but not all} mouse strains

mRNA levels for the housekeeping gene $\beta$-actin in all four experimental mouse strains showed no difference from wild-type controls ( $p>0.05$, data not shown) and served to normalize levels of BDNF mRNA. Specifically, BDNF mRNA levels were expressed as a ratio of copies of BDNF mRNA/copies of $\beta$-actin mRNA. BDNF mRNA levels from these four strains of wild-type mice did not differ from one another ( $p=0.95$, one-way ANOVA).

BDNF mRNA levels were determined in transgenic mice at ages consistent with heavy cortical plaque load, comparable with late-stage $\mathrm{AD}$, in all three strains. RT-PCR analysis of frontoparietal cortex obtained from homozygous $A P P^{N L h}$ mice containing only the Swedish APP mutation exhibited a significant 55\% decrease in BDNF mRNA levels compared with wild-type littermate mice $(p=0.020)$ (Fig. 1). APP $P^{N L h} / P S-1^{P 264 L}$ mice demonstrated a significant $60 \%$ decrease in BDNF mRNA levels $(p=0.006)$ (Fig. 1). PS-1 $1^{P 264 L}$ mice with the PS-1 mutation alone exhibited intermediate BDNF mRNA levels, although there was no significant difference between BDNF mRNA levels in $P S-1^{P 264 L}$ and either $A P P^{N L h} / P S-1^{P 264 L}(p=0.192)$ or control ( $\left.p=0.125\right)$ (Fig. 1) mice. Consistent with these results, TgCRND8 mice expressing an $A P P$ double mutation (Swedish and Indiana) exhibited a significant 35\% decrease in BDNF mRNA levels compared with wild-type littermates ( $p=0.018$ ) (Fig. 1). In contrast, neither $A P P^{\text {swe }} / P S-1^{M 146 V}$ mice nor PS-1 $1^{M 146 V}$ mice showed any change in BDNF mRNA levels compared with control mice $(p=0.364)$ (Fig. 1). However, as in the $P S-1^{P 264 L}$ strain, BDNF mRNA levels in the $P S-1^{M 146 V}$ mice showed a trend toward reduction.

Ts65Dn mice contain an additional copy of $\sim 130$ genes including the App gene. They show significant atrophy and degeneration of basal forebrain cholinergic neurons that are rescued by deleting the extra copy of App (Salehi et al., 2006). These mice exhibit elevated levels of App in the absence of any significant $A \beta$ increase (Reeves et al., 1995; Holtzman et al., 1996). Ts65Dn mice showed no difference in BDNF mRNA levels compared with $2 \mathrm{~N}$ littermates ( $p=0.177$ ) (Fig. 1), demonstrating that overproduction of $\mathrm{A} \beta$, but not App, is involved in BDNF gene downregulation.

\section{Characterization of $A \boldsymbol{\beta}$ assemblies in mouse brain homogenates}

To further examine which species of $\mathrm{A} \beta$ plays a major role in $\mathrm{BDNF}$ downregulation in these transgenic mouse models of $\mathrm{AD}$, we used Western blotting to examine cortical homogenates. We found a high-molecular-weight $(\sim 115 \mathrm{kDa}) \mathrm{A} \beta$ assembly in $A P P^{N L h} / P S-1^{P 264 L}$ and TgCRND8 mice (Fig. $2 A$ ) that totally disappeared from the soluble fraction after incubation in $10 \mathrm{mM}$ $\mathrm{Ca}^{2+}$, as previously described for protofibrils (Isaacs et al., 2006). The insoluble fraction (pellet) contained increased levels of species with molecular weights of $>150 \mathrm{kDa}$, possibly fibrillar $\mathrm{A} \beta$, and several distinct bands at lower molecular weights, including small amounts of the $\sim 115 \mathrm{kDa}$ assembly.

To further characterize the $\sim 115 \mathrm{kDa} A \beta$ species recognized by antibody $6 \mathrm{E} 10$ (Fig. $2 \mathrm{~B}$ ), brain tissue homogenates from each strain were tested by Western blotting with an antibody raised against ADDLs, NU-2 (Lambert et al., 1998, 2007). Extremely strong $\mathrm{A} \beta^{\star}$ signals (Lesné et al., 2006) (56 kDa 12-mers, as indicated in Fig. 2) and other low-molecular-weight $A \beta$ soluble oligomers $(<80 \mathrm{kDa})$ were found in all strains, but the higher-molecularweight soluble assemblies at a molecular weight of $\sim 115 \mathrm{kDa}$ were strongly evident only in $A P P^{N L h}$ and TgCRND8 strains (Fig. 
$2 B$, NU-2). NU-2 recognized two different bands in $A P P^{N L h}$ and TgCRND8 transgenic mice $(>110 \mathrm{kDa})$ (Fig. $2 B)$, including the high-molecular-weight band detected by $6 \mathrm{E} 10$. To demonstrate that the high-molecular-weight signal did not originate from soluble APP, the APPspecific antibody 22C11 detected soluble APP in all strains of mice at a molecular weight of $\sim 110 \mathrm{kDa}$ (Fig. 2 B, 22C11).

\section{Quantification of the $\sim 115 \mathrm{kDa}$ oligomer in transgenic and trisomic mice}

Semiquantitative Western blotting in these mouse models showed that the amounts of the $\sim 115 \mathrm{kDa}$ oligomer were different in TgCRND8 and $A P P^{N L h} /$ $P S-1^{P 264 L}$ mice compared with $A P P^{\text {swe }} / P S$ $1^{M 146 V}$ and Ts65Dn mice. These experiments revealed virtually none of this larger oligomer in $A P P^{\text {swe }} / P S-1 M^{146 V}$ and Ts65Dn mice, but high amounts in both TgCRND8 and $A P P^{N L h} / P S-1^{P 264 L}$ mice (Fig. $3 A$ ). Interestingly, strong $\sim 115 \mathrm{kDa}$ oligomer bands were apparent for three of the five $A P P^{s w e} / P S-1^{M 146 V}$ mice (data not shown). There were no large oligomers in Ts65Dn mice (Fig. 3D) or in any of the corresponding wild-type control mice examined (Fig. 3C). $\beta$-Actin did not vary between strains (Fig. 3B).

\section{Correlation between BDNF mRNA and $\sim 115 \mathrm{kDa}$ oligomer levels}

Levels of the $\sim 115 \mathrm{kDa}$ oligomer in each sample were quantified by densitometry and compared with the corresponding BDNF mRNA levels determined by real-time quantitative RTPCR. Results showed a strong relationship of this species to lower BDNF mRNA levels ( $p=0.005)$, although there were large variations of BDNF mRNA levels in $A P P^{\text {swe }} / P S-1^{M 146 V}$ mice. These four strains of mice were divided into two groups: (1) "decreased BDNF" (TgCRND8 and $A P P^{N L h} / P S-1^{P 264 L}$ mice) and (2) "unchanged BDNF" (APP swe $/ P S-1^{M 146 V}$ and Ts65Dn). Comparing these two groups for $\sim 115 \mathrm{kDa}$ oligomer levels, we found that the "decreased BDNF" group had significantly higher levels of this oligomer than did the "unchanged BDNF" group $(p<0.01)$, with no difference in $\beta$-actin levels between these two groups. Interestingly, among the five $A P P^{\text {swe }} / P S-1^{M 146 V}$ mice examined, mutant mice with a strong oligomer signal showed significantly lower BDNF expression than did the mice with fewer large oligomers $(p=0.049)$, suggesting that formation of this $\sim 115 \mathrm{kDa}$ oligomer plays a major role in $\mathrm{BDNF}$ downregulation in these transgenic mice.

\section{Correlation between BDNF mRNA and $A \boldsymbol{\beta}_{40}$ and $A \boldsymbol{\beta}_{42}$}

Since the assembly state of $A \beta$ is dependent on the amount and composition of $\mathrm{A} \beta$ ( $\mathrm{A} \beta_{40}$ and/or $\mathrm{A} \beta_{42}$ ) (Bitan et al., 2003) and the ratio of $A \beta_{42} / A \beta_{40}$ is a better indication of $A D$ pathology than either $\mathrm{A} \beta_{40}$ or $\mathrm{A} \beta_{42}$ alone (Lewczuk et al., 2004), we performed ELISAs for $\mathrm{A} \beta_{40}$ and $\mathrm{A} \beta_{42}$ in cortical homogenates from each mouse. This analysis revealed that $\mathrm{A} \beta_{42}$, but not $\mathrm{A} \beta_{40}$, was elevated in mice with high levels of $\sim 115 \mathrm{kDa}$ oligomer expression compared with those with low levels. $\mathrm{A} \beta_{42}$ levels were threefold higher in mice with the larger oligomer than in mice not express-
Table 2. Analysis of total BDNF mRNA in transgenic mouse strains

\begin{tabular}{|c|c|c|c|}
\hline Transgenic strain & $\begin{array}{l}\text { Number of mice } \\
\text { (gender) }\end{array}$ & Age (months) & $\begin{array}{l}p \text { value } \\
\text { (tg versus wt) }\end{array}$ \\
\hline$A P P^{N L h} / P S-1^{P 264 L}$ & $7(4 \mathrm{M}, 3 \mathrm{~F})$ & $15-18$ & $0.006^{* *}$ \\
\hline$A P P^{N L h}$ & $4(3 \mathrm{M}, 1 \mathrm{~F})$ & $15-18$ & $0.020^{*}$ \\
\hline$P S-1^{P 264 L}$ & $6(1 \mathrm{M}, 5 \mathrm{~F})$ & $15-18$ & 0.125 \\
\hline Wild type & $3(1 \mathrm{M}, 2 \mathrm{~F})$ & $15-18$ & \\
\hline APPswe $/ P S-1^{M 146 V}$ & $5(5 \mathrm{M}, 0 \mathrm{~F})$ & $21-24$ & 0.364 \\
\hline PS-1 $1^{M 146 V}$ & $7(7 \mathrm{M}, 0 \mathrm{~F})$ & $20-24$ & 0.364 \\
\hline Wild type & $7(5 \mathrm{M}, 2 \mathrm{~F})$ & $19-22$ & \\
\hline TgCRND8 & $6(4 \mathrm{M}, 2 \mathrm{~F})$ & 11 & $0.018^{*}$ \\
\hline Wild type & $8(3 \mathrm{M}, 5 \mathrm{~F})$ & 11 & \\
\hline Ts65Dn & 13 (13 M, OF) & $16-22$ & 0.177 \\
\hline $2 \mathrm{~N}$ & $4(4 \mathrm{M}, 0 \mathrm{~F})$ & $18-20$ & \\
\hline
\end{tabular}

M, Male; F, female; tg, transgenic; wt, wild type. ${ }^{*} p<0.05$; ${ }^{* *} p<0.01$.

ing them $(p=0.04)$, but $\mathrm{A} \beta_{40}$ was found at comparable levels in all of the transgenic mice examined $(p=0.46)$. Furthermore, $\mathrm{A} \beta_{42}$, but not $\mathrm{A} \beta_{40}$, was significantly higher in "decreased BDNF" than in "unchanged BDNF" mice ( $p=0.03$, data not shown). Notably, the ratio of $\mathrm{A} \beta_{42} / \mathrm{A} \beta_{40}$ was highly correlated with decreased BDNF mRNA levels in these mice $(r=-0.54, p=0.045)$ (Fig. 4).

Transcripts III and IV are responsible for total BDNF mRNA decrease in mouse brain

BDNF gene expression is controlled by multiple promoters regulating production of $>10$ different transcripts (Pruunsild et al., 2007). Transcripts I, II, III, and V (now known as transcripts I, II, IV, and VI) are downregulated in AD cortical tissue (Garzon et al., 2002). Transcripts I, III, IV, and VI are expressed in cortical tissues of mouse brain (Aid et al., 2007). These transcripts are highly homologous to their counterparts in human beings and are regulated by similar mechanisms; for example, transcript IV is the most highly expressed transcript 

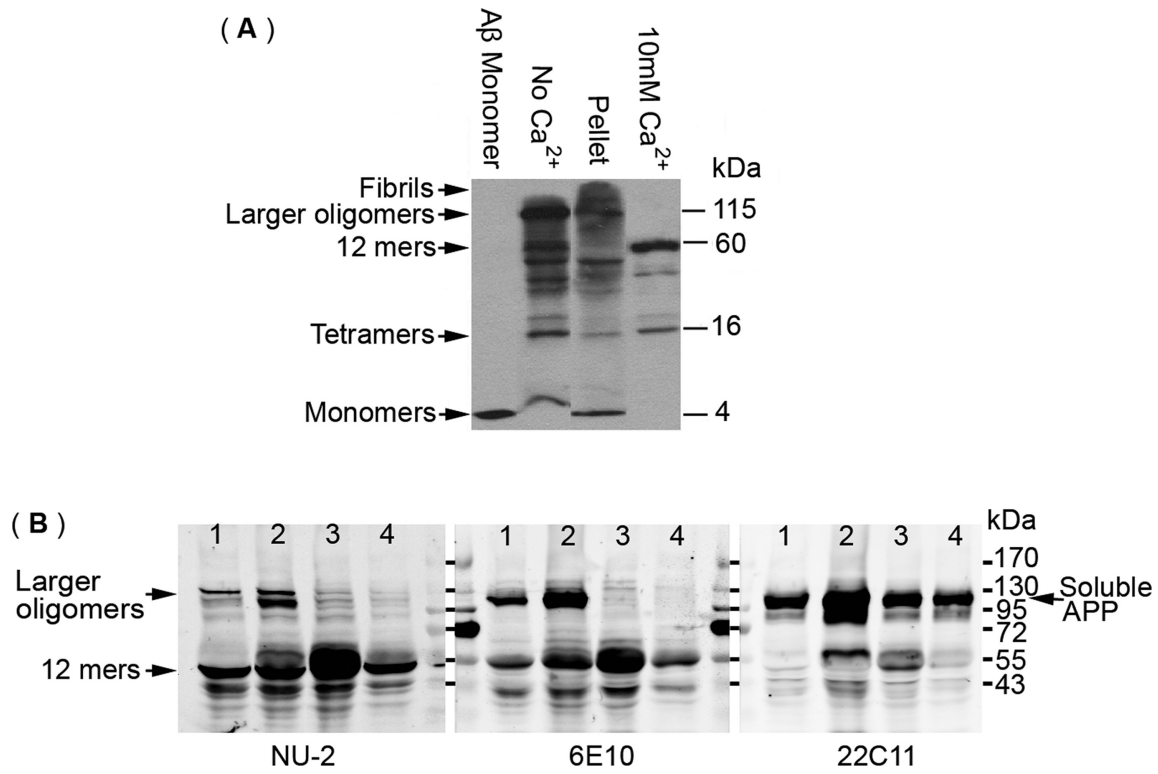

Figure 2. $\quad A, \mathrm{Ca}^{2+}$ treatment of transgenic mouse cortical homogenates. Western blot of $A P P^{N L h} / P S-7^{P 264 L}$ homogenates treated with calcium to precipitate large oligomers/protofibrils as described in Materials and Methods and detected with antibody 6E10. Oligomers of $\sim 115 \mathrm{kDa}$ ( "No $\mathrm{Ca}^{2+}$ ") disappeared from the soluble fraction after $\mathrm{Ca}^{2+}$ treatment ("10 $\mathrm{mm} \mathrm{Ca}^{2+"}$ ) and appeared as insoluble species ("Pellet"). $B$, Comparison of $A \beta$ species in four strains of mice with three different monoclonal antibodies, an ADDL-specific antibody (NU-2), A $\beta$-cross-reactive antibody6E10, and the APP-specific antibody 22C11. Lane 1, APPN/L/PS-1 ${ }^{\text {P264L }}$ mice; lane 2, TgCRND8 mice; lane 3, APP $^{\text {swe }} /$ PS $^{-1} \mathrm{I}^{\text {M146V }}$ mice; lane 4, Ts65Dn mice. Note: each lane contained $30 \mu \mathrm{g}$ of total protein.

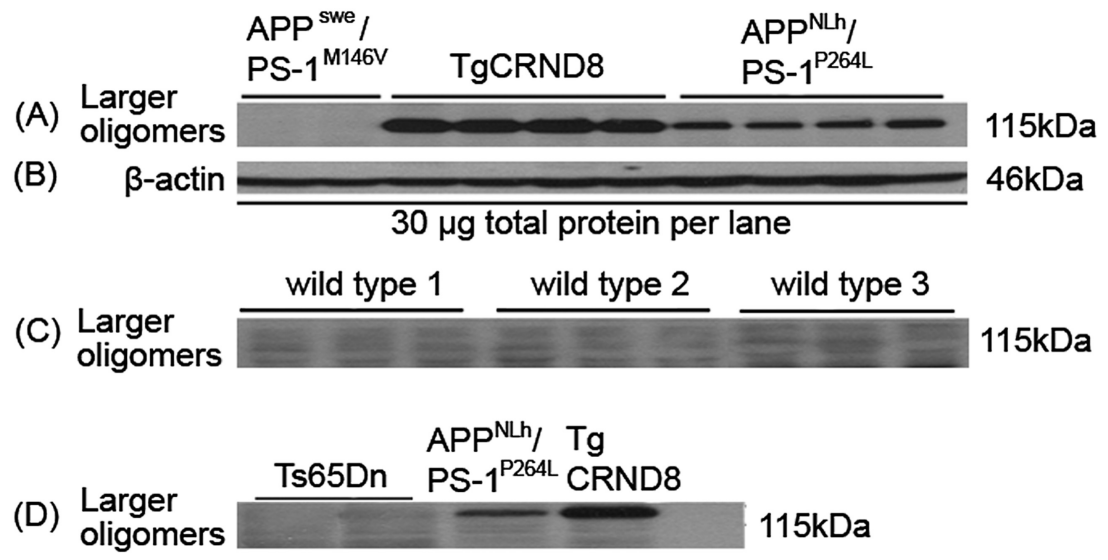

Figure 3. $2 A \beta$ complement of different transgenic mouse strains by Western blotting. $A$ shows a representative Western blot of $\sim 115 \mathrm{kDa}$ oligomers in APP $P^{N L h}$ and TgCRND8 mice but not in APP $P^{\text {swe }} / \mathrm{PS}^{-} 7^{M 146 \mathrm{~V}}$ mice. $\boldsymbol{B}$ shows the corresponding $\beta$-actin blot. C shows no $\sim 115 \mathrm{kDa}$ oligomer signals in wild-type mice from each group, but there are weak signals of $A \beta$ monomers (data not shown) and other conformations. D shows no $\sim 115 \mathrm{kDa}$ signals in Ts65Dn mice compared with other AD transgenic mice.

in both mouse and human cortical tissue (Aid et al., 2007; Garzon and Fahnestock, 2007). The exception is mouse transcript III, which exhibits only $60 \%$ homology to human transcript III; the latter is not expressed in human cortex (Garzon and Fahnestock, 2007). In TgCRND8 mice, transcript III was decreased by $33 \%(p=0.02)$ and transcript IV was decreased by $29 \%$ ( $p=0.04$ ) compared with wild-type controls (Fig. 5). Transcript II is not expressed in cortical tissues of mouse brain (Aid et al., 2007). Although transcripts I and VI are downregulated in $\mathrm{AD}$, the corresponding counterparts in mouse showed no significant decrease compared with their age-matched wild-type littermates $(p>0.05)$ (Fig. 5).

\section{Discussion}

The amyloid cascade hypothesis postulates $\mathrm{A} \beta$ overproduction as the initial insult in AD (Selkoe, 1994). However, although soluble $A \beta$ is now thought to be the toxic species (Hardy and Selkoe, 2002), which of the soluble $A \beta$ aggregates from dimers to high-molecularweight oligomers and protofibrils is responsible is a matter of debate (Caughey and Lansbury, 2003). One downstream effect of $A \beta$ overexpression is decreased BDNF levels, which may lead to neuronal and synaptic dysfunction and eventual neurodegeneration. BDNF is required for survival and function of hippocampal, cortical, basal forebrain, and entorhinal cortex neurons, all areas of the brain affected by AD (Knusel et al., 1992; Ghosh et al., 1994; Lowenstein and Arsenault, 1996; Ando et al., 2002). BDNF is also an important mediator of synaptic plasticity (Kang and Schuman, 1996; McAllister et al., 1999; Lu, 2003; Bramham and Messaoudi, 2005); heterozygous BDNF knock-out mice, which exhibit decreases in BDNF comparable to those of subjects with $\mathrm{AD}$, demonstrate defective long-term potentiation which can be rescued by BDNF administration (Korte et al., 1995; Patterson et al., 1996). Learning and memory deficits exhibited by transgenic mouse models of AD can also be rescued by BDNF delivery (Nagahara et al., 2009). In this study, we found a positive correlation between decreased levels of BDNF mRNA, the ratio of $\mathrm{A} \beta_{42} / \mathrm{A} \beta_{40}$, and the concentration of $\sim 115 \mathrm{kDa}$ oligomers produced in three transgenic AD mouse strains. Only transgenic mice expressing high $\mathrm{A} \beta_{42} / \mathrm{A} \beta_{40}$ ratios and this larger oligomeric $\mathrm{A} \beta$ species demonstrated significantly decreased total BDNF mRNA compared with wild-type controls.

We compared the reaction profiles of three monoclonal antibodies, NU-2 (ADDL specific), 6E10 (reacts with $\mathrm{A} \beta$ in all conformations), and 22C11 (APP specific), with mouse cortical homogenates. NU-2 strongly recognized 12 -mers $\left(A \beta^{\star}\right)$ in all four strains of $\mathrm{AD}$ and Down syndrome mice, demonstrating that these small $\mathrm{A} \beta$ oligomers are not responsible for the difference in BDNF levels between these mouse strains. 22C11 strongly recognized a $100 \mathrm{kDa}$ band (soluble APP) in all four strains of $\mathrm{AD}$ and Down syndrome mice, demonstrating that the highmolecular-weight band specific to $A P P^{N L h}$ and TgCRND8 transgenic mice is not APP. However, NU-2 and 6E10 detected strong signals for the $\sim 115 \mathrm{kDa}$ oligomer in $A P P^{N L h}$ and TgCRND8 transgenic mice but very weak signals in both $A P P^{\text {swe }} / P S-1$ and Ts65Dn mice, implicating this high- 


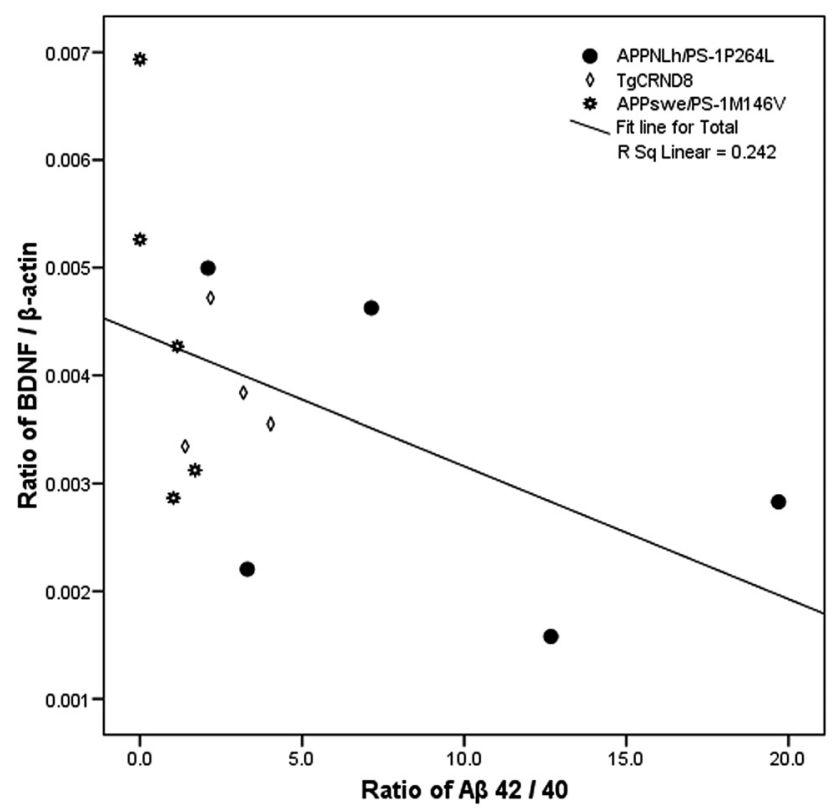

Figure 4. Correlation between $A \beta_{42} / A \beta_{40}$ ratio and BDNF mRNA levels in transgenic mice. BDNF and $\beta$-actin mRNA was measured by real-time RT-PCR, and $A \beta_{40}$ and $A \beta_{42}$ in cortex of transgenic mice were measured by sandwich ELISA. The ratio of $A \beta_{42} / A \beta_{40}$ was negatively correlated with BDNF mRNA levels in these transgenic mice. $r=-0.54, p=0.045$, Spearman rank correlation. $\mathrm{RSq}, R^{2}$.

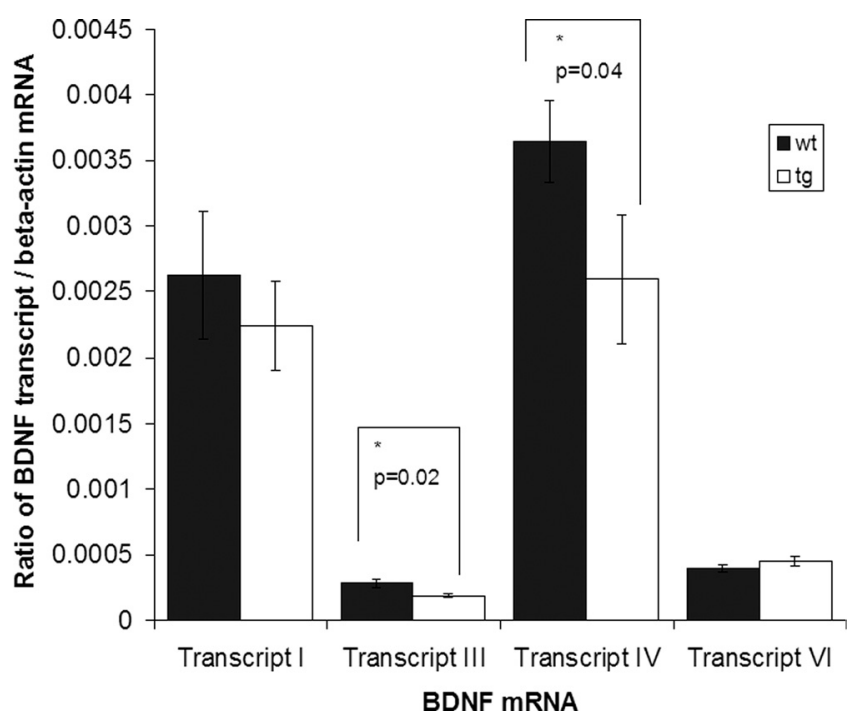

Figure 5. Expression of BDNF transcripts containing exons I, III, IV, and VI in TgCRND8 (tg) compared with wild-type (wt) littermates. Means of triplicates were evaluated by unpaired Student's $t$ test. $n=8$ for wild type and $n=6$ for TgCRND8. Error bars represent SEM.

molecular-weight species in BDNF downregulation. Precipitation experiments (Isaacs et al., 2006) showed that these species were unstable in high calcium, a property described earlier for preparations enriched in synthetic protofibrils. The structure of the $\sim 115 \mathrm{kDa}$ oligomer has not yet been determined as protofibrillar, however, and nonfibrillar $\mathrm{A} \beta$ oligomers of this size have been described (Klein, 2002; LeVine, 2004). Similar high-molecular-weight $\mathrm{A} \beta$ assemblies have been shown to induce cognitive and memory defects in TgCRND8 mice (McLaurin et al., 2006), suggesting that these larger oligomeric forms of $\mathrm{A} \beta$ are toxic to the CNS.

$\mathrm{A} \beta_{42} / \mathrm{A} \beta_{40}$ ratios are strongly correlated with decreased
BDNF levels in the present report. The rate of amyloid deposition, as well as the levels of both $\mathrm{A} \beta_{40}$ and $\mathrm{A} \beta_{42}$, vary considerably depending on the APP mutation(s) and the promoters thereof (Rockenstein et al., 2003). For example, the Swedish mutation, located at the $\mathrm{N}$ terminus of APP, favors $\beta$-secretase action resulting in a six- to eightfold increase in $\mathrm{A} \beta$, consisting of both the $\mathrm{A} \beta_{40}$ and $\mathrm{A} \beta_{42}$ fragments (Citron et al., 1992; Cai et al., 1993; Haass et al., 1995). However, the Indiana mutation flanking the $\gamma$-secretase site does not increase levels of total $A \beta$ but shifts generation of amyloid to the longer, fibrillogenic $\mathrm{A} \beta_{42}$ fragment (Clark and Goate, 1993; Suzuki et al., 1994). The $\mathrm{A} \beta_{42}$ fragment nucleates rapidly, is more fibrillogenic than $\mathrm{A} \beta_{40}$, and is the initiation component of amyloid deposits (Burdick et al., 1992; Jarrett et al., 1993; Roher et al., 1993). Consistent with this literature, we showed that $\mathrm{A} \beta_{42} / \mathrm{A} \beta_{40}$ ratios are higher in TgCRND8 and $A P P^{N L h}$ mice than in the other strains. Although $\mathrm{A} \beta_{40}$ levels were detectable but not significantly different in all three strains of $\mathrm{AD}$ mice, $\mathrm{A} \beta_{42}$ was detectable only in those mice expressing $\sim 115$ $\mathrm{kDa}$ oligomers. These results further support $\mathrm{A} \beta_{42}$ as a key triggering factor in the pathogenesis of FAD (Siman et al., 2000).

Studies of the PS-1 mutation report a 1.5 - to 2 -fold elevation of the $\mathrm{A} \beta_{42} / \mathrm{A} \beta_{40}$ ratio (Citron et al., 1992; Cai et al., 1993; Haass et al., 1995; Borchelt et al., 1997). In addition, the nature of the amyloid- $\beta$ produced in mutated PS-1 mice differs from that in transgenic APP mice. Transgenic APP mice contain the human $\mathrm{A} \beta$ sequence, which differs from mouse $\mathrm{A} \beta$ by three amino acids and is more fibrillogenic than mouse $A \beta$ (Dyrks et al., 1993; Reaume et al., 1996). Mice expressing only the PS-1 mutation, however, contain the mouse App gene, resulting in production of mouse $A \beta$. Both $P S-1^{P 264 L}$ and $P S-1^{M 146 V}$ transgenic mice demonstrate a trend toward decreased BDNF mRNA levels but no significant change in BDNF mRNA levels compared with controls. Therefore, the levels and species of mouse $\mathrm{A} \beta_{42}$ produced by mutated $P S-1$ are neither sufficient nor fibrillogenic enough to significantly compromise BDNF mRNA expression.

Overproduction of App in Ts65Dn mice caused no change in BDNF mRNA expression compared with normal disomic mice. Although the Ts65Dn mice contain an extra copy of the App gene, they do not display age-related amyloid plaque deposition (Reeves et al., 1995). Moreover, these Down syndrome mice exhibit no increase in $\mathrm{A} \beta$ compared with controls (Holtzman et al., 1996 ) and less formation of the $\sim 115 \mathrm{kDa}$ oligomer. In contrast, $A P P^{N L h}$ and TgCRND8 mice contain mutations in APP resulting in $A \beta$ overproduction and aggregation, as well as early learning and memory deficits (Chishti et al., 2001; Chang et al., 2006). Furthermore, TgCRND8 mice exhibit neurodegenerative changes as well (Bellucci et al., 2006). Both these transgenic mouse strains exhibit extremely high levels of $\sim 115 \mathrm{kDa}$ oligomers and downregulation of cortical BDNF mRNA, supporting a role for $\mathrm{A} \beta$ aggregation in compromised BDNF levels and deficits in neuronal function in AD.

The BDNF gene is complex, consisting of unique $5^{\prime}$ untranslated exons controlled by multiple promoters, each individually spliced to a common $3^{\prime}$ BDNF protein coding region (Aid et al., 2007; Pruunsild et al., 2007). These transcripts are differentially regulated in a tissue-specific, developmentally specific, and insult-specific manner (Metsis et al., 1993; Timmusk et al., 1995). Information on regulation of specific BDNF transcripts can provide clues to the mechanisms of regulation. Our previous study (Garzon et al., 2002) 
determined that in $\mathrm{AD}$ cortex, BDNF transcription is decreased specifically via downregulation of transcripts I, II, III, and V (transcripts III and V are now transcripts IV and VI in the new nomenclature) (Pruunsild et al., 2007). Furthermore, we demonstrated that oligomeric $\mathrm{A} \beta$ downregulates transcript IV in human neuroblastoma cells in culture (Garzon and Fahnestock, 2007). In that study, the aggregated $A \beta$ consisted of a mixture of oligomers including dimers, trimers, and an assortment of material of from $\sim 50 \mathrm{kDa}$ to $>100 \mathrm{kDa}$. We did not attempt to determine which of those species was responsible for BDNF downregulation in vitro. In the current study, we show that high levels of soluble $\sim 115 \mathrm{kDa}$ oligomeric $\mathrm{A} \beta$ are responsible for downregulation of BDNF transcripts III and IV in TgCRND8 mice compared with wild-type controls. Transcript III, which is regulated by methylation in mouse brain (Aid et al., 2007), is not expressed in human cortex (Garzon and Fahnestock, 2007) and exhibits only 60\% homology between mouse and human. Transcript IV, however, is highly conserved between mouse and human, is the most highly expressed transcript in human cortex, and is regulated by activity-dependent CREB phosphorylation (Shieh et al., 1998; Tao et al., 1998; Tong et al., 2001, 2004; Garzon and Fahnestock, 2007). Decreased CREB phosphorylation is a well documented phenomenon in AD and its mouse models (Silva et al., 1998; Yamamoto-Sasaki et al., 1999) and provides clues to further understanding the mechanism of large $\mathrm{A} \beta$ oligomer-mediated toxicity.

In summary, we demonstrate that transgenic mouse strains expressing high $\mathrm{A} \beta_{42} / \mathrm{A} \beta_{40}$ ratios and $\sim 115 \mathrm{kDa}$ SDS-stable $\mathrm{A} \beta$ oligomers exhibit significantly decreased cortical BDNF mRNA levels. These findings suggest that the effect of $A \beta$ on decreased $\mathrm{BDNF}$ expression is specific to the aggregation state of $\mathrm{A} \beta$ and is dependent on large oligomer and/or protofibril formation.

\section{References}

Aid T, Kazantseva A, Piirsoo M, Palm K, Timmusk T (2007) Mouse and rat BDNF gene structure and expression revisited. J Neurosci Res $85: 525-535$

Ando S, Kobayashi S, Waki H, Kon K, Fukui F, Tadenuma T, Iwamoto M, Takeda Y, Izumiyama N, Watanabe K, Nakamura H (2002) Animal model of dementia induced by entorhinal synaptic damage and partial restoration of cognitive deficits by BDNF and carnitine. J Neurosci Res 70:519-527.

Bellucci A, Luccarini I, Scali C, Prosperi C, Giovannini MG, Pepeu G, Casamenti F (2006) Cholinergic dysfunction, neuronal damage and axonal loss in TgCRND8 mice. Neurobiol Dis 23:260-272.

Bitan G, Kirkitadze MD, Lomakin A, Vollers SS, Benedek GB, Teplow DB (2003) Amyloid beta-protein (Abeta) assembly: Abeta 40 and Abeta 42 oligomerize through distinct pathways. Proc Natl Acad Sci U S A 100:330-335.

Borchelt DR, Ratovitski T, van Lare J, Lee MK, Gonzales V, Jenkins NA, Copeland NG, Price DL, Sisodia SS (1997) Accelerated amyloid deposition in the brains of transgenic mice coexpressing mutant presenilin 1 and amyloid precursor proteins. Neuron 19:939-945.

Bramham CR, Messaoudi E (2005) BDNF function in adult synaptic plasticity: the synaptic consolidation hypothesis. Prog Neurobiol 76:99-125.

Burdick D, Soreghan B, Kwon M, Kosmoski J, Knauer M, Henschen A, Yates J, Cotman C, Glabe C (1992) Assembly and aggregation properties of synthetic Alzheimer's A4/beta amyloid peptide analogs. J Biol Chem 267:546-554.

Cai XD, Golde TE, Younkin SG (1993) Release of excess amyloid beta protein from a mutant amyloid beta protein precursor. Science 259:514-516.

Caughey B, Lansbury PT (2003) Protofibrils, pores, fibrils, and neurodegeneration: separating the responsible protein aggregates from the innocent bystanders. Annu Rev Neurosci 26:267-298.

Chang KA, Kim HS, Ha TY, Ha JW, Shin KY, Jeong YH, Lee JP, Park CH, Kim S, Baik TK, Suh YH (2006) Phosphorylation of amyloid precursor pro- tein (APP) at Thr668 regulates the nuclear translocation of the APP intracellular domain and induces neurodegeneration. Mol Cell Biol 26:4327-4338.

Chishti MA, Yang DS, Janus C, Phinney AL, Horne P, Pearson J, Strome R, Zuker N, Loukides J, French J, Turner S, Lozza G, Grilli M, Kunicki S, Morissette C, Paquette J, Gervais F, Bergeron C, Fraser PE, Carlson GA, et al. (2001) Early-onset amyloid deposition and cognitive deficits in transgenic mice expressing a double mutant form of amyloid precursor protein 695. J Biol Chem 276:21562-21570.

Citron M, Oltersdorf T, Haass C, McConlogue L, Hung AY, Seubert P, VigoPelfrey C, Lieberburg I, Selkoe DJ (1992) Mutation of the beta-amyloid precursor protein in familial Alzheimer's disease increases beta-protein production. Nature 360:672-674.

Clark RF, Goate AM (1993) Molecular genetics of Alzheimer's disease. Arch Neurol 50:1164-1172.

Connor B, Young D, Yan Q, Faull RL, Synek B, Dragunow M (1997) Brainderived neurotrophic factor is reduced in Alzheimer's disease. Brain Res Mol Brain Res 49:71-81.

Dyrks T, Dyrks E, Masters CL, Beyreuther K (1993) Amyloidogenicity of rodent and human beta A4 sequences. FEBS Lett 324:231-236.

Ferrer I, Marín C, Rey MJ, Ribalta T, Goutan E, Blanco R, Tolosa E, Martí E (1999) BDNF and full-length and truncated TrkB expression in Alzheimer disease. Implications in therapeutic strategies. J Neuropathol Exp Neurol 58:729-739.

Flood DG, Reaume AG, Dorfman KS, Lin YG, Lang DM, Trusko SP, Savage MJ, Annaert WG, De Strooper B, Siman R, Scott RW (2002) FAD mutant PS-1 gene-targeted mice: increased A beta 42 and A beta deposition without APP overproduction. Neurobiol Aging 23:335-348.

Garzon D, Yu G, Fahnestock M (2002) A new brain-derived neurotrophic factor transcript and decrease in brain-derived neurotrophic factor transcripts 1, 2 and 3 in Alzheimer's disease parietal cortex. J Neurochem 82:1058-1064.

Garzon DJ, Fahnestock M (2007) Oligomeric amyloid decreases basal levels of brain-derived neurotrophic factor (BDNF) mRNA via specific downregulation of BDNF transcripts IV and V in differentiated human neuroblastoma cells. J Neurosci 27:2628-2635.

Ghosh A, Carnahan J, Greenberg ME (1994) Requirement for BDNF in activity-dependent survival of cortical neurons. Science 263:16181623.

Gong Y, Chang L, Viola KL, Lacor PN, Lambert MP, Finch CE, Krafft GA, Klein WL (2003) Alzheimer's disease-affected brain: presence of oligomeric A beta ligands (ADDLs) suggests a molecular basis for reversible memory loss. Proc Natl Acad Sci U S A 100:10417-10422.

Haass C, Lemere CA, Capell A, Citron M, Seubert P, Schenk D, Lannfelt L, Selkoe DJ (1995) The Swedish mutation causes early-onset Alzheimer's disease by beta-secretase cleavage within the secretory pathway. Nat Med 1:1291-1296.

Hardy J, Selkoe DJ (2002) The amyloid hypothesis of Alzheimer's disease: progress and problems on the road to therapeutics. Science 297:353-356.

Hock C, Heese K, Hulette C, Rosenberg C, Otten U (2000) Region-specific neurotrophin imbalances in Alzheimer disease: decreased levels of brainderived neurotrophic factor and increased levels of nerve growth factor in hippocampus and cortical areas. Arch Neurol 57:846-851.

Holsinger RM, Schnarr J, Henry P, Castelo VT, Fahnestock M (2000) Quantitation of BDNF mRNA in human parietal cortex by competitive reverse transcription-polymerase chain reaction: decreased levels in Alzheimer's disease. Brain Res Mol Brain Res 76:347-354.

Holtzman DM, Santucci D, Kilbridge J, Chua-Couzens J, Fontana DJ, Daniels SE, Johnson RM, Chen K, Sun Y, Carlson E, Alleva E, Epstein CJ, Mobley WC (1996) Developmental abnormalities and age-related neurodegeneration in a mouse model of Down syndrome. Proc Natl Acad Sci U S A 93:13333-13338.

Hsiao K, Chapman P, Nilsen S, Eckman C, Harigaya Y, Younkin S, Yang F, Cole G (1996) Correlative memory deficits, Abeta elevation, and amyloid plaques in transgenic mice. Science 274:99-102.

Hyman BT (1997) The neuropathological diagnosis of Alzheimer's disease: clinical-pathological studies. Neurobiol Aging 18:S27-S32.

Isaacs AM, Senn DB, Yuan M, Shine JP, Yankner BA (2006) Acceleration of amyloid beta-peptide aggregation by physiological concentrations of calcium. J Biol Chem 281:27916-27923.

Jarrett JT, Berger EP, Lansbury PT Jr (1993) The carboxy terminus of the 
beta amyloid protein is critical for the seeding of amyloid formation: implications for the pathogenesis of Alzheimer's disease. Biochemistry 32:4693-4697.

Kang H, Schuman EM (1996) A requirement for local protein synthesis in neurotrophin-induced hippocampal synaptic plasticity. Science 273:1402-1406.

Klein WL (2002) Abeta toxicity in Alzheimer's disease: globular oligomers (ADDLs) as new vaccine and drug targets. Neurochem Int 41:345-352.

Knüsel B, Beck KD, Winslow JW, Rosenthal A, Burton LE, Widmer HR, Nikolics K, Hefti F (1992) Brain-derived neurotrophic factor administration protects basal forebrain cholinergic but not nigral dopaminergic neurons from degenerative changes after axotomy in the adult rat brain. J Neurosci 12:4391-4402.

Korte M, Carroll P, Wolf E, Brem G, Thoenen H, Bonhoeffer T (1995) Hippocampal long-term potentiation is impaired in mice lacking brain-derived neurotrophic factor. Proc Natl Acad Sci U S A 92:8856-8860.

Kurt MA, Davies DC, Kidd M, Duff K, Rolph SC, Jennings KH, Howlett DR (2001) Neurodegenerative changes associated with beta-amyloid deposition in the brains of mice carrying mutant amyloid precursor protein and mutant presenilin-1 transgenes. Exp Neurol 171:59-71.

Lacor PN, Buniel MC, Furlow PW, Clemente AS, Velasco PT, Wood M, Viola KL, Klein WL (2007) Abeta oligomer-induced aberrations in synapse composition, shape, and density provide a molecular basis for loss of connectivity in Alzheimer's disease. J Neurosci 27:796-807.

Lambert MP, Barlow AK, Chromy BA, Edwards C, Freed R, Liosatos M, Morgan TE, Rozovsky I, Trommer B, Viola KL, Wals P, Zhang C, Finch CE, Krafft GA, Klein WL (1998) Diffusible, nonfibrillar ligands derived from Abeta1-42 are potent central nervous system neurotoxins. Proc Natl Acad Sci U S A 95:6448-6453.

Lambert MP, Velasco PT, Chang L, Viola KL, Fernandez S, Lacor PN, Khuon D, Gong Y, Bigio EH, Shaw P, De Felice FG, Krafft GA, Klein WL (2007) Monoclonal antibodies that target pathological assemblies of Abeta. J Neurochem 100:23-35.

Lesné S, Koh MT, Kotilinek L, Kayed R, Glabe CG, Yang A, Gallagher M, Ashe $\mathrm{KH}$ (2006) A specific amyloid-beta protein assembly in the brain impairs memory. Nature 440:352-357.

LeVine H 3rd (2004) Alzheimer's beta-peptide oligomer formation at physiologic concentrations. Anal Biochem 335:81-90.

Lewczuk P, Esselmann H, Otto M, Maler JM, Henkel AW, Henkel MK, Eikenberg O, Antz C, Krause WR, Reulbach U, Kornhuber J, Wiltfang J (2004) Neurochemical diagnosis of Alzheimer's dementia by CSF Abeta42, Abeta42/Abeta40 ratio and total tau. Neurobiol Aging 25:273-281.

Lowenstein DH, Arsenault L (1996) The effects of growth factors on the survival and differentiation of cultured dentate gyrus neurons. J Neurosci 16:1759-1769.

Lu B (2003) Pro-region of neurotrophins: role in synaptic modulation. Neuron 39:735-738.

McAllister AK, Katz LC, Lo DC (1999) Neurotrophins and synaptic plasticity. Annu Rev Neurosci 22:295-318.

McGowan E, Sanders S, Iwatsubo T, Takeuchi A, Saido T, Zehr C, Yu X, Uljon S, Wang R, Mann D, Dickson D, Duff K (1999) Amyloid phenotype characterization of transgenic mice overexpressing both mutant amyloid precursor protein and mutant presenilin 1 transgenes. Neurobiol Dis 6:231-244.

McLaurin J, Kierstead ME, Brown ME, Hawkes CA, Lambermon MH, Phinney AL, Darabie AA, Cousins JE, French JE, Lan MF, Chen F, Wong SS, Mount HT, Fraser PE, Westaway D, St George-Hyslop P (2006) Cyclohexanehexol inhibitors of Abeta aggregation prevent and reverse Alzheimer phenotype in a mouse model. Nat Med 12:801-808.

Metsis M, Timmusk T, Arenas E, Persson H (1993) Differential usage of multiple brain-derived neurotrophic factor promoters in the rat brain following neuronal activation. Proc Natl Acad Sci U S A 90:88028806.

Mirra SS, Heyman A, McKeel D, Sumi SM, Crain BJ, Brownlee LM, Vogel FS, Hughes JP, van Belle G, Berg L (1991) The Consortium to Establish a Registry for Alzheimer's Disease (CERAD). Part II. Standardization of the neuropathologic assessment of Alzheimer's disease. Neurology 41:479-486.

Mufson EJ, Counts SE, Fahnestock M, Ginsberg SD (2007) Cholinotrophic molecular substrates of mild cognitive impairment in the elderly. Curr Alzheimer Res 4:340-350.

Nagahara AH, Merrill DA, Coppola G, Tsukada S, Schroeder BE, Shaked GM, Wang L, Blesch A, Kim A, Conner JM, Rockenstein E, Chao MV, Koo EH, Geschwind D, Masliah E, Chiba AA, Tuszynski MH (2009) Neuroprotective effects of brain-derived neurotrophic factor in rodent and primate models of Alzheimer's disease. Nat Med 15:331-337.

Patterson SL, Abel T, Deuel TA, Martin KC, Rose JC, Kandel ER (1996) Recombinant BDNF rescues deficits in basal synaptic transmission and hippocampal LTP in BDNF knockout mice. Neuron 16:11371145.

Peng S, Wuu J, Mufson EJ, Fahnestock M (2005) Precursor form of brainderived neurotrophic factor and mature brain-derived neurotrophic factor are decreased in the pre-clinical stages of Alzheimer's disease. J Neurochem 93:1412-1421.

Phillips HS, Hains JM, Armanini M, Laramee GR, Johnson SA, Winslow JW (1991) BDNF mRNA is decreased in the hippocampus of individuals with Alzheimer's disease. Neuron 7:695-702.

Pruunsild P, Kazantseva A, Aid T, Palm K, Timmusk T (2007) Dissecting the human BDNF locus: bidirectional transcription, complex splicing and multiple promoters. Genomics 90:397-406.

Reaume AG, Howland DS, Trusko SP, Savage MJ, Lang DM, Greenberg BD, Siman R, Scott RW (1996) Enhanced amyloidogenic processing of the beta-amyloid precursor protein in gene-targeted mice bearing the Swedish familial Alzheimer's disease mutations and a "humanized" Abeta sequence. J Biol Chem 271:23380-23388.

Reeves RH, Irving NG, Moran TH, Wohn A, Kitt C, Sisodia SS, Schmidt C, Bronson RT, Davisson MT (1995) A mouse model for Down syndrome exhibits learning and behaviour deficits. Nat Genet 11:177-184.

Rockenstein E, Adame A, Mante M, Moessler H, Windisch M, Masliah E (2003) The neuroprotective effects of Cerebrolysin in a transgenic model of Alzheimer's disease are associated with improved behavioral performance. J Neural Transm 110:1313-1327.

Roher AE, Lowenson JD, Clarke S, Woods AS, Cotter RJ, Gowing E, Ball MJ (1993) beta-Amyloid-(1-42) is a major component of cerebrovascular amyloid deposits: implications for the pathology of Alzheimer disease. Proc Natl Acad Sci U S A 90:10836-10840.

Sadowski M, Pankiewicz J, Scholtzova H, Ripellino JA, Li Y, Schmidt SD, Mathews PM, Fryer JD, Holtzman DM, Sigurdsson EM, Wisniewski T (2004) A synthetic peptide blocking the apolipoprotein E/beta-amyloid binding mitigates beta-amyloid toxicity and fibril formation in vitro and reduces beta-amyloid plaques in transgenic mice. Am J Pathol 165:937-948.

Salehi A, Delcroix JD, Belichenko PV, Zhan K, Wu C, Valletta JS, TakimotoKimura R, Kleschevnikov AM, Sambamurti K, Chung PP, Xia W, Villar A, Campbell WA, Kulnane LS, Nixon RA, Lamb BT, Epstein CJ, Stokin GB, Goldstein LS, Mobley WC (2006) Increased App expression in a mouse model of Down's syndrome disrupts NGF transport and causes cholinergic neuron degeneration. Neuron 51:29-42.

Selkoe DJ (1994) Alzheimer's disease: a central role for amyloid. J Neuropathol Exp Neurol 53:438-447.

Shieh PB, Hu SC, Bobb K, Timmusk T, Ghosh A (1998) Identification of a signaling pathway involved in calcium regulation of BDNF expression. Neuron 20:727-740.

Siegel GJ, Chauhan NB (2000) Neurotrophic factors in Alzheimer's and Parkinson's disease brain. Brain Res Brain Res Rev 33:199-227.

Silva AJ, Kogan JH, Frankland PW, Kida S (1998) CREB and memory. Annu Rev Neurosci 21:127-148.

Siman R, Reaume AG, Savage MJ, Trusko S, Lin YG, Scott RW, Flood DG (2000) Presenilin-1 P264L knock-in mutation: differential effects on A $\beta$ production, amyloid deposition, and neuronal vulnerability. J Neurosci 20:8717-8726.

Suzuki N, Cheung TT, Cai XD, Odaka A, Otvos L Jr, Eckman C, Golde TE, Younkin SG (1994) An increased percentage of long amyloid beta protein secreted by familial amyloid beta protein precursor (beta APP717) mutants. Science 264:1336-1340.

Tao X, Finkbeiner S, Arnold DB, Shaywitz AJ, Greenberg ME (1998) Ca2+ influx regulates BDNF transcription by a CREB family transcription factor-dependent mechanism. Neuron 20:709-726.

Timmusk T, Lendahl U, Funakoshi H, Arenas E, Persson H, Metsis M (1995) Identification of brain-derived neurotrophic factor promoter regions me- 
diating tissue-specific, axotomy-, and neuronal activity-induced expression in transgenic mice. J Cell Biol 128:185-199.

Tong L, Thornton PL, Balazs R, Cotman CW (2001) Beta-amyloid-(1-42) impairs activity-dependent cAMP-response element-binding protein signaling in neurons at concentrations in which cell survival is not compromised. J Biol Chem 276:17301-17306.

Tong L, Balazs R, Thornton PL, Cotman CW (2004) Beta-amyloid peptide at sublethal concentrations downregulates brain-derived neurotrophic factor functions in cultured cortical neurons. J Neurosci 24:6799-6809.

Townsend M, Shankar GM, Mehta T, Walsh DM, Selkoe DJ (2006) Effects of secreted oligomers of amyloid beta-protein on hippocampal synaptic plasticity: a potent role for trimers. J Physiol 572:477-492.
Walsh DM, Selkoe DJ (2007) A beta oligomers-a decade of discovery. J Neurochem 101:1172-1184.

Walsh DM, Klyubin I, Fadeeva JV, Cullen WK, Anwyl R, Wolfe MS, Rowan MJ, Selkoe DJ (2002) Naturally secreted oligomers of amyloid beta protein potently inhibit hippocampal long-term potentiation in vivo. Nature 416:535-539.

Yamamoto-Sasaki M, Ozawa H, Saito T, Rosler M, Riederer P (1999) Impaired phosphorylation of cyclic AMP response element binding protein in the hippocampus of dementia of the Alzheimer type. Brain Res 824:300-303.

Yankner BA (2000) The pathogenesis of Alzheimer's disease. Is amyloid beta-protein the beginning or the end? Ann N Y Acad Sci 924:26-28. 